\title{
Chronic constipation: modern view on the problem. A review
}

\author{
I. M. Leshchyshyn, Y. M. Susak, O. I. Okhots'ka, \\ P. L. Byk, L. Y. Markulan, O. V. Panchuk
}

Bogomolets National Medical University, Kyiv

\author{
Ivan Leshchyshyn: ileshchyshyn3@gmail.com \\ I. M. Leshchyshyn, http://orcid.org/0000-0003-1429-2756 \\ Y.M. Susak, http://orcid.org/0000-0002-5102-485X \\ O.I. Okhots'ka, http://orcid.org/0000-0002-3468-8179 \\ P. L. Byk, http://orcid.org/0000-0002-2215-3978 \\ L. Y. Markulan, http://orcid.org/0000-0003-2879-5012 \\ O.V. Panchuk, http://orcid.org/0000-0001-6962-6851
}

\begin{abstract}
Chronic constipation is a frequently diagnosed heterogeneous pathology that significantly impairs the quality of life in all population groups and its frequency increases with age. It commonly affects up to $10-15 \%$ of the population. There are numerous classifications of constipation due to a great number of disorders that cause it. The types of constipation are identified based on the etiology or mechanism of its development. Different criteria are used to specify the categorization of constipation, but it is still difficult to find one general classification including all types of constipation. The Rome IV criteria categorize disorders of chronic constipation into four subgroups. The treatment depends on the subtype. The significant increase of constipation cases is observed nowadays. This disorder is facilitated by a sedentary lifestyle, insufficient amount of fiber and fluid in the diet, a wide range of diseases that directly lead to the development of chronic constipation, congenital and acquired pathologies, abnormal intake of laxatives and opioids or a combination of these factors. Despite numerous publications on slow transit constipation, the latter is still the subject of research for many specialists. A lot of recent scientific works have been dedicated to the immunohistochemical studies of interstitial pacemaker cells. The numbers of markers they express were found. Consequently, the investigations of modern scientists are aimed to develop and implement new laboratory methods for determining the indications for surgical treatment depending on a diagnosed disorder of the intestinal neurophysiology. These methods will ensure a differentiated selection of patients for surgical treatment. The step approach to the diagnosis of chronic constipation allows choosing an adequate treatment method in order to improve symptoms, the quality of life, and patient satisfaction. The literature review indicates that surgery still remains the most radical treatment method for patients with slow transit constipation.
\end{abstract}

\section{KEYwords}

slow transit constipation, laxatives, total colectomy, ileorectal anastomosis.

ARTICLE • Received 2021-11-15 • Received in revised form 2021-11-23

(C) General Surgery, 2021

Particular attention to constipation syndrome has been paid since the middle of the 19th century. The first articles on this problem appeared in the scientific medical periodicals. Most of them were descriptive and included the clinical cases from the medical practice and the results of autopsies. Much attention was paid to the clinical picture and such treatment methods as cleansing enemas and various herbal medicines.

At the beginning of the 20th century, Sir William Arbuthnot Lane, a famous Scottish physician and scientist, firstly described refractory chronic disease in women and paid attention to its clinical picture, proposed to treat them surgically. In tribute to the scientist, this type of constipation is called «Lane's disease» [11]. In 1905, the possible causes of constipation syndrome were analyzed, and the characteristic clinical symptoms were described [49].

Thus, the history of chronic constipation treatment began in the depths of centuries. The scientists correctly identified the main links in the development of the disease, and gave them accurate descriptions. In those scientific works, previously unknown mechanisms of constipation were revealed, and new 
classifications were introduced. However, to this day, many scientific discoveries on pathogenesis and treatment of chronic constipation are still made.

Chronic constipation commonly affects up to $10-15 \%$ of the population and impairs the quality of life. There are numerous classifications of constipation due to a great number of disorders that cause it. The types of constipation are identified based on the etiology or mechanism of its development. Different criteria are used to specify the categorization of constipation, but it is still difficult to find one general classification including all types of constipation. The Rome IV criteria categorize disorders of chronic constipation into four subgroups: (a) functional constipation, (b) irritable bowel syndrome with constipation, (c) opioid-induced constipation, and (d) functional defecation disorders, including inadequate defecation propulsion and dyssynergic defecation. The first-line management for these disorders is focused on diet, lifestyle and the use of standard over-the-counter laxatives. The treatment is provided according to the subtype [6].

Constipation is defined as difficulties in defecation: infrequent bowel movements, hard or lumpy stools, excessive straining, and sensation of incomplete evacuation or blockage and, in some instances, the use of manual maneuvers to facilitate evacuation. Acute symptoms typically last up to one week and are commonly precipitated by a change in diet and/or lifestyle (low fiber intake, decreased physical activity, stress, etc.). Chronic constipation is commonly defined by symptoms that persist up to 3 months [48].

\section{Epidemiology}

The prevalence of chronic constipation ranges from $3 \%$ to $27 \%$ [76].

The global prevalence of chronic constipation has been estimated as $14 \%$ based on a large metanalysis of 45 surveys, comprising 261,040 adults [80]. In healthy people constipation occurs occasionally as a result of diet, traveling or emotional factors. Females, aged patients and low socioeconomic status patients are affected by chronic constipation more commonly $[14,80]$. The population-based survey, using the Rome IV diagnostic questionnaire, revealed the following data: the prevalence of chronic constipation is approximately $9 \%$, with $\sim 6 \%$ of functional constipation (FC) and the remaining $3 \%$ split evenly between irritable bowel syndrome with constipation (IBS-C) and opioid-induced constipation (OIC) [61]. A global epidemiological study of functional gastrointestinal disorders is currently underway. Functional defecation disorders, such as inadequate defecatory propulsion and dyssynergic defecation, always require special diagnostic methods [48, 72]

Constipation may be a symptom of different etiologies, and for this reason, many diagnostic approaches and treatment options are available, ranging from simple lifestyle changes and general measures to sophisticated pharmacological treatments and surgical intrusions. [56, 58, 74] The prevalence of chronic constipation increases with age [19, 82] and consequently is expected to rise over the next few years [81]. European Society of Neurogastroenterology and Motility (ESNM) decided to develop European guidelines to improve the quality of life in patients suffering from common functional and motor disorders. The ESNM guidelines for chronic constipation were also discussed.

Predominance of females in the prevalence of constipation was mostly reported by different authors [62]. According to the studies, the mean female/ male ratio was 1.78 (median 1.58), but differed according to the definition of constipation (1.7 for Rome I, 1.8 for Rome II, and 2.3 for self-reporting of constipation). The epidemiological study in patients with functional constipation based on Rome III Criteria also showed a higher prevalence in female students $(17.4 \%)$ than in male students (12.5\%) [52].

Hormonal factors play a significant role in constipated women: luteal phase of the menstrual cycle and the effect of progesterone in pregnant women, pelvic floor muscles damage during childbirth or gynecological surgery. Premenopausal and older women were also compared in order to measure a colon transit time. Premenopausal women aged 25-49 years were shown to have a longer transit time than older women (64.0 vs 59.5 hours; difference 4.6 hours, $95 \%$ CI $1.1-8.1$ hours) [32, 67]. The latter means less pronounced gender differences in constipation prevalence in the older population.

Genetic factors may also play a role in FC [16]. Patients with a positive family history of FC showed younger age at onset (median 11-20 years vs $21-30$ years, $p<.001$ ) and longer duration of constipation ( $20 \pm 14$ vs $15 \pm 13 ; \mathrm{p}=0.016)$. Much more complications, such as symptomatic hemorrhoids, anal fissure and rectal prolapse ( $54.2 \%$ vs $40.4 \%, p=0.034$ ), fewer precipitating factors leading to the onset of constipation (35.6\% vs $49.1 \%$, $\mathrm{p}=0.037$ ), and more frequent use of digital evacuation $(27.1 \%$ vs $13.2 \%, p=0.008)$, were observed in patients with a positive family history of FC. W. Ostwani et al. [60] showed significantly higher rates of constipation in parents of children with functional, habitual constipation than in controls (30\% vs $7 \%$ and $42 \%$ vs $9 \%$, respectively; $\mathrm{p}=0.001)$. Thus, individuals of lower social, economic, and educational 
levels have a tendency toward higher constipation rates [13]. Additionally, according to another scientific study [53], constipation correlated with a low maternal educational level (1.60; 1.08-2.35). All of the abovementioned can be related to less consumption of fiber, fruit, and vegetables in low socioeconomic status groups [1].

\section{Pathophysiology}

Different pathophysiological mechanisms may lead to FC. Constipation can be classified into three categories: functional defecatory disorders, normal colonic transit, and slow colonic transit (STC) [76].

The pathophysiology of constipation, in particular STC, is not completely studied even nowadays. To understand the causes of defecation disorders, it is necessary to know its mechanism. The normal act of defecation requires a series of synchronized actions, including relaxation of puborectalis muscles, pelvic floor lowering with anorectal angle straightening, inhibition of segmental intestinal peristalsis, contraction of anterior abdominal wall muscles and, finally, relaxation of the external anal sphincter with further expulsion of fecal masses. Colorectal motility disorders presenting with constipation include slow-transit constipation (STC, colonic inertia), pelvic floor dysfunction and combination syndromes. Although sometimes it is impossible to draw a clear distinction between these factors [66].

STC typically affects young women, with the onset of symptoms before 25 in most cases. Etiopathogenesis of STC is not clear. Pelvic floor dyssynergia (anismus) is described as inappropriate contraction or failure to relax the pelvic floor during the attempt to defecate. T. Wedel et al. [88] reported that the colonic motor dysfunction in STC is associated with quantitative alterations of the enteric nervous system (oligoneuronal hypoganglionosis), which cannot be detected just by submucosal biopsy because they primarily affect myenteric plexus and external submucous plexus.

The pathogenesis of the slow-transit type of motor-evacuation disorders can be represented by the suppression of the intestinal motor activity which, in turn, slows down the transit of the contents. As a result, we observe an increase in the contact time of the intestinal contents with the mucous membrane, in the reabsorption of fluid with preserved epithelial transport, as well as in the bacterial fermentation of unabsorbed carbohydrates. A change in viscosity and a decrease in the volume of intestinal contents weaken the sensory sensitivity of the intestinal wall to tension, and inhibit its transit, thus slowing down the vicious circle.
The prolonged time of the presence of feces in the intestine leads to its thickening and decreased size, resulting in insufficient pressure on the rectum necessary for defecation reflex. Accordingly, this group of patients requires more pressure for defecation than healthy people. Various physiological and histobiochemical studies have been carried out in order to explain the phenomenon of slow-transit constipation: a decrease in cholinergic and an increase in adrenergic responses [85]; weak gastrointestinal reflex [36]; dyssynergy of rectosigmoid intestinal activity [7]; neurodegeneration [38] of the intestinal wall in the myenteric plexus ganglia and interstitial cells of Cajal (ICC; Latin interstitium - interval) [89]; abnormalities of intestinal neurotransmitters, such as substance $P$ of vasoactive intestinal peptides [45, 77], nitric acid [45, 84]. With regard to the neuropathological aspects of chronic constipation, the intestinal nervous apparatus plays the main role. Cajal cells are very important in impaired intestinal motility in chronic slow-transit constipation. The role of ICC was analyzed in STC patients, with a focus on motility. They found a significantly decreased volume of ICC in all layers of sigmoid colonic specimens in STC patients compared to controls. Neuronal structures within the colonic circular smooth muscle layer were also decreased. Interstitial cells of Cajal are cells that play an important role in the control of spontaneous motility of the gastrointestinal tract (GIT) and serve as pacemakers that set the frequency for slow waves of electrical potential for smooth muscle, which determine the frequency of peristalsis in various parts of the gastrointestinal tract [39].

Interstitial cells of Cajal are derivatives of the mesenchyme, localized in the interstitium between nerve endings and smooth muscle cells. Electrophysiological evidence of these cells in establishing the slow waves rhythm of smooth muscles was obtained at the end of the 20th century. Interstitial cells of Cajal are found in all parts of the digestive tract from the lower third of the esophagus to the internal sphincter of the anus and are widely represented in loose connective tissue. Interstitial cells of Cajal are represented by networks associated with the smooth muscles. They have close connections with the nerves that provide innervation. The morphological studies suggest that the functions of ICC in the organs of the digestive tract are as follows:

- generation of slow waves in smooth muscles (described below);

- spread of electrical phenomena in the tissues of organs;

- role of intermediates in neuromuscular transmission. 
In patients with chronic slow-transit constipation, which requires surgery due to its resistance to conservative therapy [30], the histology of resected bowel sections showed a significant decrease in the neurons number (due to the phenomenon of apoptosis) and ICC compared to control group, as well as a significant decrease in the number of intestinal glial cells (EGC) in the intermuscular and submucosal plexuses not due to apoptosis [8].

A hypothesis about a disturbance of the gut - brain interactions presents various factors of relevance that include visceral hypersensitivity, abnormalities in sensory/motor function, delayed colonic transit, and altered central perception [6]. Thus, in the instance of OIC, the cause is directly linked to the agonism of opioid receptors in the gastrointestinal tract leading to the reduced intestinal secretion and motility. OIC was introduced as a new diagnosis in the Rome IV disorders of chronic constipation. However, the Rome IV working committee opted to include OIC to help facilitate its recognition and aid further research [24].

\section{Diagnostic methods}

Anamnesis vitae, anamnesis morbi, complaints and physical examination are mandatory for evaluation of patients with constipation. The main aim of additional diagnostic procedures is exclusion of anatomic (colonoscopy, barium enema) and extracolonic causes of constipation. The next step is a 6-month conservative treatment, including dietary modifications, physical exercise, behavioral and pharmacological therapy. In case of failure to manage the problem, a referral to colonic and anorectal physiologic testing should be considered.

Chronic constipation is evaluated similarly to any other gastrointestinal complaint. That's why, its organic etiology (i.e., colorectal cancer, inflammatory bowel disease) should be initially excluded. A clinical history, gastrointestinal examination and basic laboratory tests are necessary. Further investigations to diagnose an organic pathology should then depend on whether warning signs are present [48].

If patients had symptoms of chronic constipation in the last 3 months (with the onset of at least 6 months prior to it), and no organic gastrointestinal pathology, they can be categorized according to the Rome IV criteria into one of the following diagnoses $[48,70]$.

a. Irritable bowel syndrome with constipation (IBS-C) - manifested by abdominal pain at least 1 day per week, where the pain is associated with at least two of the following:

- change in stool frequency $\rightarrow$ toward infrequent bowel movements;

- change in stool form $\rightarrow$ toward harder stools;
- related to defecation.

Patients have to report changes, when they have abnormal stools, to detect constipation and diagnose IBS-C.

b. Functional Constipation (FC) - these patients do not fulfill the criteria for IBS, because abdominal pain is absent/not predominant or occurs less than 1 day per week. Patients, who consume opiates, should be excluded from a diagnosis of functional constipation as they rather fit within the realms of opioid-induced constipation.

The symptoms of FC must include two or more of the following:

- straining (more than $25 \%$ of defecations);

- lumpy or hard stools (BSFS type 1 or 2), more than $25 \%$ of defecation;

- sensation of incomplete evacuation (more than one-fourth ( $25 \%$ ) of defecations);

- sensation of anorectal obstruction/blockage (more than one-fourth ( $25 \%$ ) of defecations);

- manual maneuvers to facilitate more than onefourth $(25 \%)$ of defecations;

- fewer than three spontaneous bowel movements per week.

c. Opioid-induced constipation - symptoms of constipation occur after initiating, changing, or increasing opioid therapy.

d. Functional defecation disorders (inadequate defecatory propulsion and dyssynergic defecation) - the criteria for IBS-C or FC, features of impaired rectal evacuation as demonstrated by two of the following three tests:

- abnormal balloon expulsion test;

- abnormal anorectal evacuation pattern with anorectal manometry (or anal surface electromyography (EMG);

- impaired rectal evacuation on defecography, but without structural lesions.

The Bristol Stool Form Scale (BSFS) is a validated tool for stool consistency assessment because stool consistency has been shown to be a more reliable indicator of colonic transit than stool frequency. There are seven types of stools [48]:

- type 1 and 2 - hard or lumpy stool;

- type 6 and 7 - loose or watery stool.

The presence of other gastrointestinal symptoms (e.g., abdominal pain, bloating, and vomiting) or warning symptoms, which include unintentional weight loss, rectal bleeding and a family history of colorectal cancer or inflammatory bowel disease, have to be assessed [1]. Also, we must take into consideration some neurological disorders, such as Parkinson's disease, or medications, such as opiates, calcium channel blockers, and tricyclic antidepressants, that can be manifested by constipation. 
According to most studies, straining, hard stools, abdominal discomfort, bloating, infrequent bowel movements, and feeling of incomplete evacuation after bowel movement were frequent symptoms of chronic constipation. [42] Patient Assessment of Constipation Symptoms (PAC-SYM) questionnaire or the Bristol stool scale help to provide the clinical evaluation of patients with constipation [6].

The Rome IV criteria include the following symptoms: (a) straining; (b) hard stools (Bristol 1-2); (c) sensation of incomplete evacuation; (d) sensation of anorectal obstruction; (e) need for manual maneuvers to facilitate evacuation; and (f) less than 3 spontaneous bowel movements per week [56].

The authors suggest the application of the $25 \%$ rule (a symptom present in $25 \%$ of stool movements) to all symptoms to facilitate the use of the criteria in the clinical setting $[61,75,78,90]$.

As mentioned in the Rome IV criteria, functional bowel disorders are an only part of the disorders with great overlap in clinical practice. Bloating and abdominal pain are typical for constipated patients. According to the recent recommendations, the diagnosis of IBS should be considered only in patients with abdominal pain [9, 10, 56, 83]. But the problem arises as a result of lack of objective biological markers for FC and IBS-C.

As a side effect of opioid intake, constipation may be observed in $81 \%$ of patients, even if they are concomitantly prescribed laxatives [2]. Due to the increasing use of opioids in Western countries, there is a strong need to rule out the use of opioids in patients with constipation, especially considering that opioid consumption is not always reported by patients $[2,26,34,56,75,90]$. Opioids exert their analgesic effects by crossing the blood - brain barrier and binding to opioid receptors within the central nervous system. Our GI tract is also abundant with opioid receptors and their agonism leads to the reduced intestinal secretion and motility, giving rise to OIC. Indeed, OIC occurs in $51-87 \%$ of patients receiving opioids for cancer and between $41 \%$ and $57 \%$ patients receiving opioids for chronic non-cancer pain [25].

\section{Physical examination}

First of all, an organic disease, the presence of abdominal masses and lymphadenopathy, as well as warning signs have to be rule out. According to the existing guidelines, the diagnosis of constipation is mainly made on the basis of symptoms alone [23, $56,90]$. A US survey showed that the most frequent symptoms of chronic constipation were straining, hard stools, abdominal discomfort, bloating, infrequent bowel movements, and feeling of incomplete evacuation after bowel movement.

Anoscopy or colonoscopy should be also provided. A digital rectal examination should be undertaken to palpate for anorectal strictures, hemorrhoids, anal fissures, to assess for perineal descent and anal sphincter relaxation; the presence of parodoxical anal contraction may imply dyssynergic defecation [70]. The sensitivity and specificity of digital rectal examination for dyssynergic defecation is $75 \%$ and $87 \%$, respectively. So, further confirmation with anorectal manometry is required, and if abnormal findings are obtained, it can be successfully treated with biofeedback.

\section{Laboratory methods}

This includes blood tests checking for anemia, inflammation, hypothyroidism, hypercalcemia, and celiac disease [48]. Although celiac disease is commonly perceived as a diarrheal illness, 1 in 10 patients present with constipation [79]. A transabdominal/vaginal ultrasound scan should also be performed in postmenopausal women with recent onset constipation, localized lower abdominal pain, bloating or distension; rarely, ovarian cancer can be the underlying cause.

\section{Instrumental methods}

a. For patients with warning symptoms, a colonoscopy or cross-sectional study should be prescribed after clinical evaluation. There is little diagnostic yield of performing a colonoscopy for chronic constipation in those without any alarm features [48]. No association between chronic constipation and the development of colorectal cancer was found [33].

b. The balloon expulsion test is used to asses rectal evacuatory disorder, such as dyssenergic defecation. The test is done by timing how long it takes a patient to evacuate a rectal balloon, filled with either $50 \mathrm{ml}$ of water or air; in health, most will evacuate within 1-2 min. However, there are important considerations for the balloon expulsion test. It can lack sensitivity as the balloon may not mimic the patients' regular stool and thus be evacuated even in those with a defecatory disorder. Some delicate issues also interfere with its specificity as, despite individuals being asked to expel the balloon whilst sitting on a commode behind a private screen, they may still not feel comfortable being outside the confines of their own toileting environment. Finally, an abnormal result cannot differentiate between inadequate defecatory propulsion, dyssynergic defecation, and a structural evacuatory disorder. As such, 
the test is commonly performed and interpreted alongside high-resolution anorectal manometry and defecography [70].

c. Anorectal manometry - for patients in whom a functional defecation disorder (inadequate defecatory propulsion and/or dyssynergic defecation), following the initial digital rectal examination or when standard medical therapy has failed [70]. During the anorectal manometry, the rectal propulsive pressure is also assessed to diagnose patients with inadequate defecatory propulsion. Normally, ARM should demonstrate adequate coordination between the increase in intrarectal pressure and anal relaxation. Weak abdominal compression and inadequate relaxation of the anal canal. The rectoanal inhibitory reflex (RAIR) depends on gut innervation. An abnormal RAIR is typically found in Hirschsprung's disease, Chagas disease [72].

The functional defecation disorders can be classified into the manometric subgroups (type I and III describe dyssynergic defecation) that are given below [70].

Type I - Adequate intrarectal propulsive pressure but increased anal sphincter pressure.

Type II-Inadequate intrarectal propulsive pressure and increased anal sphincter pressure.

Type III - Adequate intrarectal propulsive pressure but absent/insufficient anal sphincter relaxation.

Type IV - Inadequate intrarectal propulsive pressure and absent/insufficient anal sphincter relaxation.

The main purpose of functional testing is to determine the pathophysiological mechanisms of constipation and subsequently guide therapeutic measures [71].

Defecography is the most commonly used test before surgical management of constipation/evacuation disorders that aims at reversing demonstrable posterior compartment abnormalities (e.g., rectal prolapse, rectocele, high-grade intussusception), which are consistent with the presentation of symptoms. This radiological procedure dynamically images the rectum and pelvic floor during attempted defecation and also assesses functional parameters (anorectal angle at rest and straining) [70].

Colonic transit studies are indicated for patients after unsuccessful medical conservative treatment, and before surgical intervention planning [20].

Radio-opaque marker testing. Patient should swallow 10 radio-opaque markers per day for six consecutive days, followed by fluoroscopic imaging on the morning of day 7 to count the number of remaining markers; the colonic transit time can then be calculated (in days) by dividing the number of retained markers with the daily dose [65, 86]. This test is useful for the evaluation of oro-anal transit, with the advantages of low cost, simplicity, and wide availability. However, the protocols are not standardized, and the technique varies depending on the center. Usually, STC is characterized by a delayed colonic transit time [72].

None of the tests are sufficient to diagnose a defecation disorder, at least two abnormal evacuation tests are necessary to diagnose a functional defecation disorder (FDD) [70].

\section{Conservative treatment}

The first-line management of patients with constipation that is carried out at any level of the healthcare system and according to the existing recommendations [76] is presented in Fig. 1.

The initial treatment of chronic constipation is always conservative and includes basic lifestyle and dietary modifications. There are main principles of conservative treatment for patients with chronic constipation: general health issues, high fiber diet and medications (laxatives and enemas). The general health issues are body training (e.g., jogging, hiking, and gymnastics) and enough fluid intake (at least 1.5-2.0 L/day). Taking into consideration a systematic review and metanalysis of the nine randomized controlled trials, involving 680 participants, physical training can be recommended for chronic constipation as its benefits and feasibility are evidenced by these studies [31]. The effects of exercise may be observed through modulation of anti-inflammatory and anti-oxidative mechanisms [37]. Hence, patients should increase their physical activity as tolerated, starting with a 20 -minute walk (e.g., roughly 1 mile) each day. Usually, patients are told to increase their fluid intake. A randomized controlled study in patients with chronic constipation showed that those allocated to $2 \mathrm{~L}$ of mineral water per day increased stool frequency compared to the group allocated ad libitum fluid intake $(\sim 1 \mathrm{~L}$ per day); however, the findings may be confounded by the mineral water containing magnesium [3]. Additionally, patients should be informed that physiological bowel activity is high in the morning after getting up. That is why, patients should use the «gastrocolic reflex» in having enough time after breakfast for evacuation («toilet training»). Some suppositories, which increase rectal contractility, can augment the reflex. The physician should talk to patient in order to identify the patient's concerns and understanding of the disorder. It's very important to involve the patient in treatment decisions rather than issuing directives. This approach improves patient satisfaction and compliance with the prescribed therapy, as well as reduces subsequent physician visits [24]. 


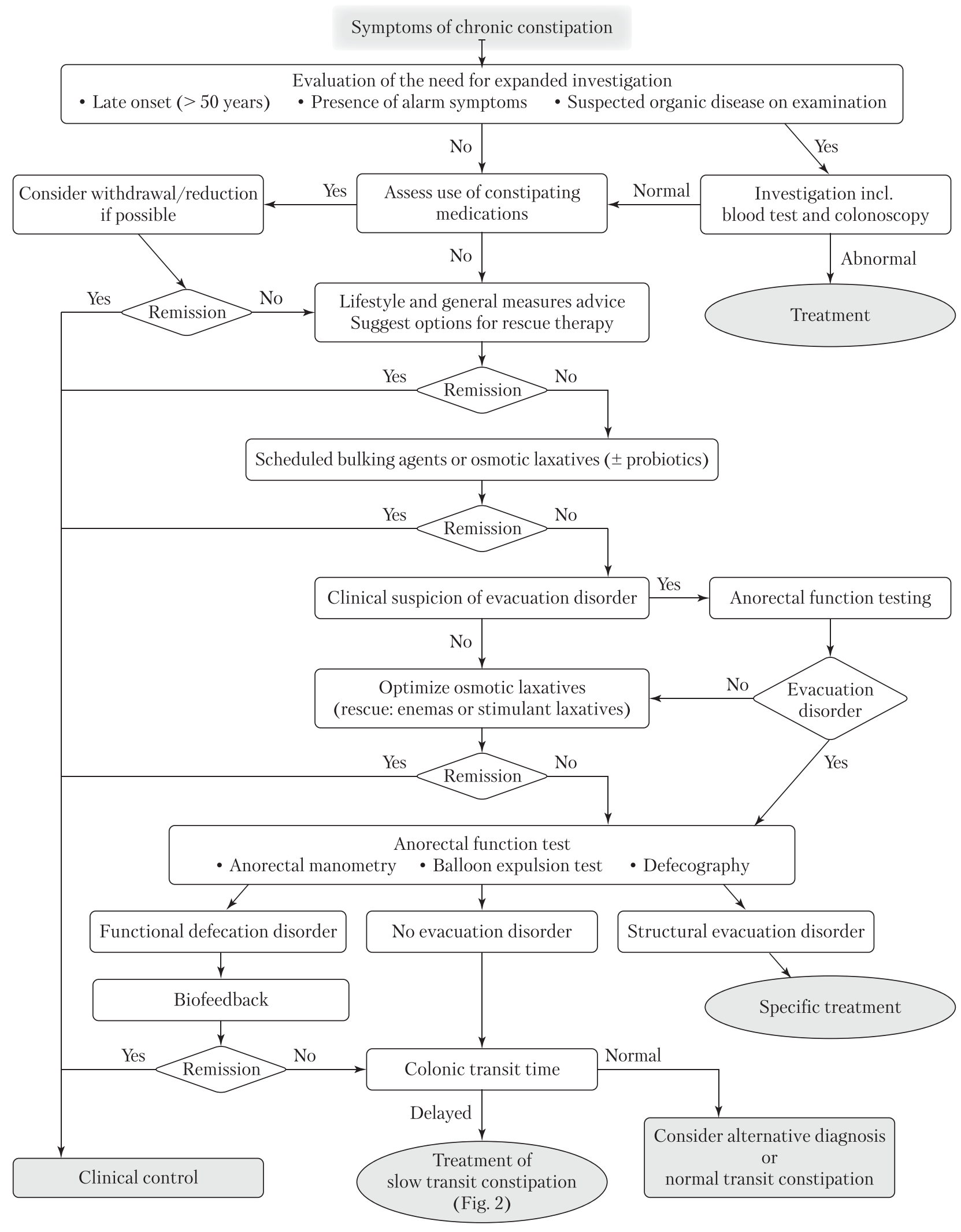

Figure 1. First-line management of patients presenting with constipation at any level of the healthcare system [76]. Defined as difficult, unsatisfactory, or infrequent defecation for at least 3 previous months [58]. Rescue therapy may include suppositories or rectal enemas, if accepted by the patient, or the use of fiber or osmotic laxatives upon request. The level of evidence is very low. It is strongly recommended [82]. The use of probiotics seems promising; however, no strong evidence of their effectiveness exists [19]. When available, anorectal function testing may be indicated at this stage when there is a clinical suspicion of an evacuation disorder (manual maneuvers, hemorrhoids, prolapse or rectocele, painful evacuation, etc.) [81]. Alternatively, other treatments, including prokinetics or secretagogues, could be tried 
Patient with poor response to general measures, bulking agents and osmotic laxatives

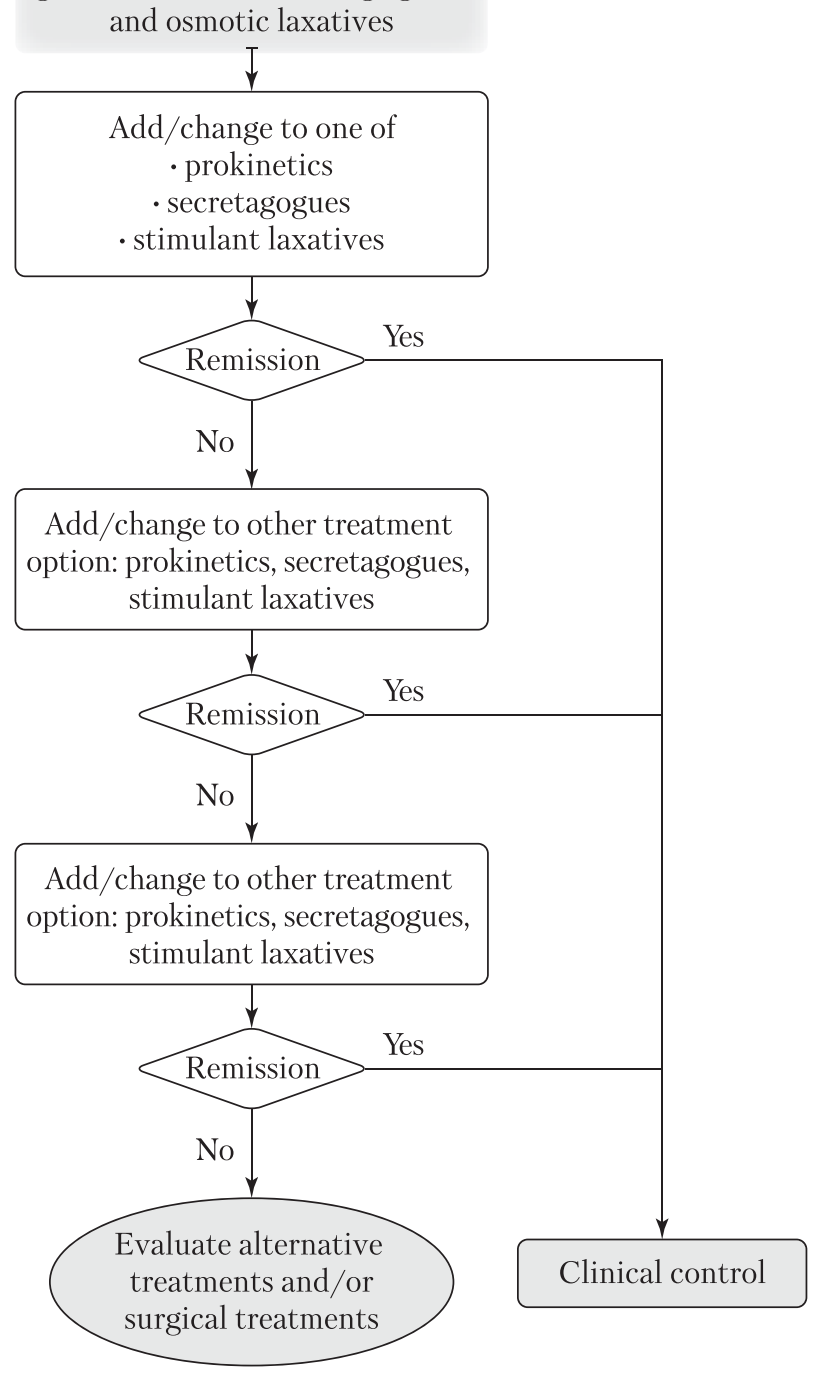

Figure 2. Treatment of constipation that is not caused by an evacuation disorder and is refractory to first-line management [76]. The primary choice depends on the patient's characteristics, such as coexistence of abdominal pain or distension, cost/efficacy evaluation, and local pReferences [58]. As a rescue therapy, stimulant laxatives may be used, as well as suppositories, rectal enemas, or rectal irrigation

Supplementing the diet with fiber can be of benefit because it serves to enhance the water holding properties of the stool, form gels to provide stool lubrication, and provide bulk for the stool and stimulate peristalsis.

The American College of Gastroenterology (ACG) issued recommendations, based on these six trials, in which fiber and soluble fiber in particular are considered effective in the management of chronic constipation [28]. The latter appear to relate to the relief of constipation, which further supports the use of soluble fiber in patients with constipation, either FC or IBS-C.
Bulking agents, such as psyllium, bind water and prevent absorption of water from the lumen. It leads to the increased small bowel water content and increased colonic volumes [55]. These effects can explain both positive impacts of bulking agents, resulting in increased stool frequency, and potential side effects, such as bloating, distension, flatulence, and cramping. The presence of adverse effects may limit the use of insoluble fiber, especially if the increased fiber intake is not introduced gradually [28].

\section{Pharmacological treatment}

Laxatives. Osmotic laxatives were found to be superior to a placebo for FC first-line treatment according to six randomized controlled trials [29]. Polyethylene glycol was superior to lactulose and non-inferior to prucalopride [5, 22]. A randomized controlled trial demonstrated its superiority over a placebo with regard to the improved stool frequency, stool consistency and straining [17]. Bloating, gas, and loose stools can be dose dependent adverse effects. Stimulant laxatives are also commonly used when osmotic laxative fail in FC patients [28]. According to two relatively recent randomized controlled trials, bisacodyl and sodium picosulphate were found to be superior to a placebo $[44,57]$. The most common adverse effects associated with stimulant laxatives are abdominal pain, cramping, and loose stools.

The evidence, supporting the usefulness of saline laxatives, especially polyethylene glycol (PEG), is strong. A few substantial, high-quality trials suggest that PEG works better than a placebo in improving symptoms in patients with chronic constipation [29]. Also, PEG is proved to be superior to lactulose in patients with chronic constipation, resulting in more frequent and looser stools, and less abdominal pain according to a Cochrane review. PEG also increases the number of spontaneous complete bowel movements, improves stool consistency, and reduces severity of straining, without clearly affecting abdominal pain, in patients with IBS-C. The most common side effects with PEG are diarrhea and abdominal pain.

Only some clinical experience maintains the benefits of osmotic laxatives in patients with chronic constipation. Moreover, side effects, such as abdominal cramping and bloating, limit clinical usefulness of the unabsorbed mono/disaccharides, sugar alcohols, lactulose, lactitol, mannitol, and sorbitol. In a randomized controlled trial, dried plums (containing sorbitol, which acts as an osmotic laxative, dietary fibers and polyphenols) were found to be useful, palatable and more effective than psyllium for the treatment of mild-to-moderate constipation [4]. 
If osmotic laxatives fail, stimulant laxatives are commonly used [28]. Bisacodyl and sodium picosulphate were proved to be superior to a placebo [44]. Abdominal pain, cramping, and loose stools were the most common side effects.

Luminally acting prosecretory agents have been evaluated in patients with either FC or IBS-C, where they can be used as a second-line therapy after standard laxatives. Linaclotide and Plecanatide, guanylate cyclase- $\mathrm{C}$ agonists were included in this group. Activation of this receptor on colonic epithelial cells leads to the increased intracellular production of cyclic guanosine monophosphate. Dual action was observed for these laxatives, comprising salt and water secretion into the intestinal lumen, and attenuation of visceral afferent pain signaling. Additionally, linaclotide and plecanatide improve stool consistency and frequency, and reduce abdominal pain. According to the randomized controlled trials, these laxatives demonstrated their superiority compared to a placebo in the treatment of FC and IBS-C [12, 18, 50, 68, 69]. The most common side effect was diarrhea in up to $20 \%$ of patients. Lubiprostone is a chloride-channel activator that stimulates intestinal fluid secretion. Lubiprostone was proved to be better than a placebo and relieved the symptoms of FC and OIC. The good effect was seen at 1 month but was no longer significant at 3 months $[51,41]$. Diarrhea and nausea were the most common side effects $(\sim 8 \%)$.

$5 \mathrm{HT}_{4}$ agonists (prucalopride). Serotonin (5-hydroxytryptamine, 5-HT) accelerates gastrointestinal motility, and Prucalopride provides its effect through being a $5 \mathrm{HT}_{4}$ receptor agonist. Analyzing six randomized controlled trials, prucalopride was proved to be superior to a placebo in patients with functional constipation and OIC toward achieving at least 3 spontaneous bowel movements per week. Common side effects included diarrhea and headache, but the symptoms normally disappeared within the first week of treatment [15].

Peripherally acting mu-opioid receptor antagonists (PAMORAs). PAMORAs (i.e., nalexagol, naldemedine, methylnaltrexone) reduce the symptoms of OIC by blocking the mu-opioid receptors within the GI tract, but as they do not cross the blood-brain barrier, they neither diminish the central analgesic effect of opioids nor induce withdrawal symptoms. PAMORAs were found to be superior to a placebo in the treatment of OIC [54]. According to a recent European expert consensus statement, PAMORAs have to be prescribed if standard laxatives fail. Prucalopride and lubiprostone in OIC patients can be prescribed after standard laxatives but before PAMORA [6].

\section{Future therapies}

Japan is the only country that has approved the drug for the treatment of chronic constipation. Elobixibat is an ileal bile acid transporter inhibitor. It induces a state of bile acid malabsorption, thereby increasing the colonic bile acid pool and leading to increased stool frequency and looser stool consistency. A randomized, double-blind, placebo controlled, phase 3 trial and an open label, single arm, phase 3 trial conducted in Japan found that elobixibat resolved the symptoms of FC in a short period of time, and was well tolerated during both a short and long-term treatment [59].

\section{Anorectal biofeedback}

Biofeedback is a training technique that can be used effectively to manage individuals with dyssynergic defecation. This technique can also improve slow transit constipation as a secondary phenomenon to dyssynergic defecation. According to the randomized controlled trials, biofeedback seems to be superior to a standard therapy (i.e., laxatives) for dyssynergic defecation [21, 40]. Home-based biofeedback improves bowel symptoms and its physiology is similar to office-based biofeedback according to a recent randomized controlled trial [73].

\section{Transanal irrigation}

Transanal irrigation is useful in patients with a neurogenic bowel dysfunction. It is also indicated for patients with FC in whom pharmacological therapies have failed before surgery. Transanal irrigation can improve bowel function and the quality of life, but more than one third of patients continue their treatment within the first year [43].

\section{Nerve stimulation}

Sacral nerve stimulation is an invasive surgical procedure with high morbidity rates (due to displacement, pain, wound infection, and hematoma) ranging between $13 \%$ and $34 \%$ [64]. It was initially indicated for patients with refractory cases of chronic constipation with treatment success ranging between $57 \%$ and $86 \%$. Thus, sacral nerve stimulation for refractory chronic constipation is an expensive, invasive procedure which lacks proven benefit [6].

\section{Colonic surgery}

Sir William Arbuthnot Lane was the first to propose surgical treatment of constipation [49]. The treatment methods of resistant constipation remained 
unchanged for many years; surgery was a method of despair; it was indicated when conservative management failed. The indications for surgical treatment, its extent, the timing of conservative treatment and the criteria for evaluating its effectiveness were not clearly defined for a long time [11].

According to the scientific reviews, patients with slow-transit constipation, refractory to a medical therapy and not associated with pelvic outlet obstruction or functional problems, demonstrate sufficient rates of clinical improvement $(50 \%-100 \%)$ after total abdominal colectomy with ileorectal anastomosis (TA CIRA), as compared with a segmental colon resection, after which failure rates for the treatment of slow-transit constipation can be as high as $100 \%$ [47], [87]. Morbidity after TA CIRA includes anastomotic leak $(1 \%-11 \%)$, bowel obstruction (8-33\%) [63], and prolonged postoperative ileus (24\%). Laparoscopic TA CIRA also demonstrated great results [35]. Although constipation generally improves after TA CIRA for slow-transit constipation, patients may experience diarrhea, abdominal pain, fecal incontinence, and recurrent constipation [63]. Despite this, $>90 \%$ of patients reported that they would undergo TA-CIRA again to treat their constipation [27].

Thus, colonic resections (i.e., ileorectal anastomosis or ileostomy) are rarely indicated and should only be considered as a last resort in patients with intractable FC, in whom there is clear evidence of slow transit and where pharmacological therapies have failed despite being of optimal dosage and duration. The evidence of benefit of colonic resections is derived almost exclusively from observational studies. A systematic review of 40 articles, providing outcome data in 2045 patients, reported that colectomy may benefit some patients with FC but at the cost of substantial short-and long-term morbidity. Complications occurred in $25 \%$ of patients. Recurrent episodes of small bowel obstruction were observed in about $15 \%$ of patients in the long term, with significant burden of rehospitalization and frequent recourse to surgery. Hence, current evidence is insufficient to guide patient or procedural selection [46]. Moreover, it should be avoided in those with panenteric dysfunction, and neither does it have a role in IBSC, OIC or dyssynergic defecation.

\section{Conclusions}

Chronic constipation is still considered a functional or idiopathic disorder. However, there is recent evidence that its pathophysiological grounds may be actually due to a complex system of abnormalities of the enteric nervous system of these patients.
In particular, as reported in this review, the enteric glial cells seem to be constantly involved in constipated patients, suggesting that (at least some forms of) constipation should be considered as true neuro-gliopathies.

The last decade has seen an increase in the repertoire of pharmacological therapies available for the treatment of chronic constipation. By adopting a logical step-wise approach toward the diagnosis of chronic constipation and its individual subtypes, clinicians have the opportunity to tailor a therapy accordingly and improve symptoms, the quality of life, and patient satisfaction.

Despite numerous publications on slow transit constipation, the latter is still the subject of research for many specialists. The literature review indicates that surgery still remains the most radical treatment method for patients with slow transit constipation. A lot of recent scientific works have been dedicated to the immunohistochemical studies of interstitial pacemaker cells. The numbers of markers they express were found. Consequently, the investigations of modern scientists are aimed to develop and implement new laboratory methods for determining the indications for surgical treatment depending on a diagnosed disorder of the intestinal neurophysiology. These methods will ensure a differentiated selection of patients for surgical treatment.

\section{DECLARATION OF INTERESTS}

We declare no competing interests. The authors are responsible for the views expressed in this article and they do not necessarily represent the views, decisions, or policies of the institutions with which they are affiliated.

\section{AUTHOR CONTRIBUTIONS}

I. M. Leshchyshyn, Y. M. Susak, L. Y. Markulan: project idea and revision of its drafts; O. I. Okhots'ka, P.L. Byk: search and selection of literary sources, writing this review, making edits; O. V. Panchuk: help with finding literary sources.

\section{REFERENCES}

1. Allen L, et al. Socioeconomic status and non-communicable disease behavioural risk factors in low-income and lower-middleincome countries: a systematic review. The Lancet Global Health, 2017;5.3:e277-89. doi: 10.1016/S2214-109X(17)30058-X.

2. Andresen V, Banerji V, Hall G, Lass A, Emmanuel AV. The patient burden of opioid induced constipation: New insights from a large, multinational survey in five European countries. UEG J. 2018;6:1254-66. doi: 10.1177/2050640618786145.

3. Anti M, Pignataro G, Armuzzi A, et al. Water supplementation enhances the effect of high-fiber diet on stool frequency and laxative consumption in adult patients with functional constipation. Hepatogastroenterology. 1998;45(21):727-32.

4. Attaluri A, Donahoe R, Valestin J, Brown K, Rao SSC. Randomized clinical trial: dried plums (prunes) vs. psyllium for constipation: Randomized clinical trial: dried plums in constipation Aliment Pharmacol Ther. 2011;33:822-8. doi: 10.1111/j.13652036.2011.04594.x 
5. Attar A, Lémann M, Ferguson A, et al. Comparison of a low dose polyethylene glycol electrolyte solution with lactulose for treatment of chronic constipation. Gut. 1999;44(2):226-30. doi 10.1136/gut.44.2.226.

6. Aziz Imran, et al. An approach to the diagnosis and management of Rome IV functional disorders of chronic constipation. Expert review of gastroenterology \& hepatology. 2020;14.1:39-46. doi: 10.1080/17474124.2020.1708718.

7. Bassotti G, de Roberto G, Castellani D, Sediari L, Morelli A. Normal aspects of colorectal motility and abnormalities in slow transit constipation. World J Gastroenterol. 2005;11:2691-6. doi: 10.3748/wjg.v11.i18.2691.

8. Bassotti G, Villanacci V, Maurer CA, et al. The role of glial cells and apoptosis of enteric neurons in the neuropathology of intractable slow transit constipation. Gut. 2006;55:41-6. doi: 10.1136/ gut.2005.073197.

9. Bellini M. Irritable bowel syndrome and chronic constipation: Fact and fiction. World J Gastroenterol. 2015;21:11362. doi: 10.3748/wjg.v21.i40.11362.

10. Bouchoucha M, Devroede G, Mary F, Bon C, Bejou B, Benamouzig R. Painful or mild pain constipation? A clinically useful alternative to classification as irritable bowel syndrome with constipation versus functional constipation. Dig Dis Sci. 2018;63:1763-73. doi: 10.1007/s10620-018-4995-6.

11. Brand R. A. Sir William Arbuthnot Lane, 1856-1943. Clinical Orthopaedics and Related Research 467.8. 2009:1939-1943. doi: 10.1007/s11999-009-0861-3.

12. Brenner DM, Fogel R, Dorn SD, et al. Efficacy, safety, and tolerability of plecanatide in patients with irritable bowel syndrome with constipation: results of two phase 3 randomized clinical trials. Am J Gastroenterol. 2018;113(5):735-45. doi: 10.1038/s41395018-0026-7.

13. Bytzer P, Howell S, Leemon M, Young LJ, Jones MP, Talley NJ. Low socioeconomic class is a risk factor for upper and lower gastrointestinal symptoms: a population based study in 15000 Australian adults. Gut. 2001;49:66-72. doi: 10.1136/gut.49.1.66.

14. Camilleri M, Ford AC, Mawe GM, et al. Chronic constipation. Nat Rev Dis Primers. 2017:3:17095. doi: 10.1038/nrdp.2017.95.

15. Camilleri M, Piessevaux H, Yiannakou Y, et al. Efficacy and safety of prucalopride in chronic constipation: an integrated analysis of six randomized, controlled clinical trials. Dig Dis Sci 2016:61(8):2357-72 doi: 10.1007/s10620-016-4147-9.

16. Chan AO, Lam KF, Hui WM, et al. Influence of positive family history on clinical characteristics of functional constipation. Clin Gastroenterol Hepatol. 2007;5:197-200. doi: 10.1016/j. cgh.2006.10.009.

17. Chapman RW, Stanghellini V, Geraint M, et al. Randomized clinical trial: macrogol/PEG 3350 plus electrolytes for treatment of patients with constipation associated with irritable bowel syndrome. Am J Gastroenterol. 2013;108(9):1508-15. doi: 10.1038/ ajg. 2013.197

18. Chey WD, Lembo AJ, Lavins BJ, et al. Linaclotide for irritable bowel syndrome with constipation: a 26-week, randomized, double-blind, placebo controlled trial to evaluate efficacy and safety. Am J Gastroenterol. 2012;107(11):1702-12. doi: 10.1038/ ajg.2012.254.

19. Chiarelli P, Brown W, McElduff P. Constipation in Australian women: prevalence and associated factors. Int Urogynecol J Pelvic Floor Dysfunct. 2000;1 1:71-8. doi: 10.1007/s001920050073.

20. Chiarioni G, Salandini L, Whitehead WE. Biofeedback benefits only patients with outlet dysfunction, not patients with isolated slow transit constipation. Gastroenterology. 2005;129(1):86-97. doi: 10.1053/j.gastro.2005.05.015.

21. Chiarioni G, Whitehead WE, Pezza V, et al. Biofeedback is superior to laxatives for normal transit constipation due to pelvic floor dyssynergia. Gastroenterology. 2006;130(3):657-64. doi 10.1053/j.gastro.2005.11.014

22. Cinca R, Chera D, Gruss HJ, et al. Randomized clinical trial: macrogol/ PEG 350+electrolytes versus prucalopride in the treatmen of chronic constipation - a comparison in a controlled environment. Aliment Pharmacol Ther. 2013;37(9):876-86. doi: 10.1111/ apt.12278.

23. Cook IJ, Talley NJ, Benninga MA, Rao SS, Scott SM. Chronic constipation: overview and challenges. Neurogastroenterol Motil. 2009;21(Suppl 2):1-8 doi: 10.1111/j.1365-2982.2009.01399.x.

24. Drossman DA. Functional gastrointestinal disorders: history, pathophysiology, clinical features and Rome IV. Gastroenterology. 2016;150(6):126-79. doi: 10.1053/i.gastro.2016.02.032.

25. Farmer $\mathrm{AD}$, Drewes $\mathrm{AM}$, Chiarioni G, et al. Pathophysiology and management of opioid induced constipation: European expert consensus statement. United European Gastroenterol J. 2019;7(1):7-20. doi: 10.1177/2050640618818305.
26. Farmer AD, Holt CB, Downes TJ, Ruggeri E, Del Vecchio S, De Giorgio R. Pathophysiology, diagnosis, and management of opioid induced constipation. Lancet Gastroenterol Hepatol. 2018;3:203-12. doi: 10.1016/S2468-1253(18)30008-6.

27. Fitz Harris GP, Garcia-Aguilar J, Parker SC, et al. Quality of life after subtotal colectomy for slow-transit constipation: both quality and quantity count. Dis Colon Rectum. 2003;46:433-40. doi: 10.1007/s10350-004-6576-3.

28. Ford AC, Moayyedi P, Lacy BE, et al. American College of Gastroenterology monograph on the management of irritable bowel syndrome and chronic idiopathic constipation. Am J Gastroenterol. 2014;1:S2-S26. doi: 10.1038/ajg.2014.187.

29. Ford AC, Suares NC. Effect of laxatives and pharmacological therapies in chronic idiopathic constipation: systematic review and metanalysis. Gut. 2011;60:209-18. doi: 10.1136/gut.2010.227132.

30. Frattini JC, Nogueras JJ. Slow transit constipation: a review of a colonic functional disorder. Clin Colon Rectal Surg. 2008;21:146-52. doi: 10.1055/s-0036-1593436.

31. Gao R, Tao Y, Zhou C, et al. Exercise therapy in patients with constipation: a systematic review and metanalysis of randomized controlled trials. Scand J Gastroenterol. 2019;54(2):169-77. doi: 10.1080/00365521.2019.1568544

32. Gonenne J, Esfandyari T, Camilleri M, et al. Effect of female sex hormone supplementation and withdrawal on gastrointestinal and colonic transit in postmenopausal women. Neurogastroenterol Motil. 2006;18:911-8. doi: 10.1111/j.13652982.2006.00808x

33. Guérin A, Mody R, Fok B, et al. Risk of developing colorectal cancer and benign colorectal neoplasm in patients with chronic constipation. Alimentary pharmacology \& therapeutics. 2014;40(1):83-92. doi: 10.1111/apt.12789.

34. Gupta A. Improving the recognition and diagnosis of opioid induced constipation in clinical practice. J Fam Pract. 2015;64(10 Suppl 1). doi: 10.1097/AJP.0000000000000852.

35. Hsiao KC, Jao SW, Wu CC, Lee TY, Lai HJ, Kang JC. Handassisted laparoscopic total colectomy for slow transit constipation. Int J Colorectal Dis. 2008;23:419-24. doi: 10.1007/s00384-007-04317

36. Hagiwara N, Tomita R. Pathophysiology of chronic constipation of the slow transit type from the aspect of the type of rectal movements. Hepatogastroenterology. 2008;55:1298-303.

37. Hajizadeh Maleki B, Tartibian B, Mooren FC, et al. Low-to-moderate intensity aerobic exercise training modulates irritable bowel syndrome through antioxidative and inflammatory mechanisms in women: results of a randomized controlled trial. Cytokine. 2018;102:18-25. doi: 10.1016/i.cyto.2017.12.016

38. Hanani M, Fellig Y, Udassin R, Freund HR. Agerelated changes in the morphology of the myenteric plexus of the human colon. Auton Neurosci. 2004; 113:71-8. doi: 10.1016/j.autneu.2004.05.007.

39. He CL, Burgart L, Wang L, et al. Decreased interstitial cell of cajal volume in patients with slow-transit constipation. Gastroenterology. 2000;118:14-21. doi: 10.1016/s0016-5085(00)70409-4.

40. Heymen S, Scarlett Y, Jones K, et al. Randomized, controlled trial shows biofeedback to be superior to alternative treatments for patients with pelvic floor dyssynergia-type constipation. Dis Colon Rectum. 2007;50(4):428-41. doi: 10.1007/s10350-0060814-9.

41. Jamal MM, Adams AB, Jansen JP, et al. A randomized, placebocontrolled trial of lubiprostone for opioid induced constipation in chronic noncancer pain. Am J Gastroenterol. 2015;110(5):72532. doi: 10.1038/ajg.2015.106.

42. Johanson JF, Kralstein J. Chronic constipation: a survey of the patient perspective: Patient perspective on constipation. Aliment Pharmacol Ther. 2007;25:599-608. doi: 10.1111/j.13652036.2006.03238.x

43. Juul T, Christensen P. Prospective evaluation of transanal irrigation for fecal incontinence and constipation. Tech Coloproctol. 2017;21(5):363-71. doi: 10.1007/s10151-017-1635-7.

44. Kamm MA, Mueller-Lissner S, Wald A, et al. Oral bisacodyl is effective and well tolerated in patients with chronic constipation. Clin Gastroenterol Hepatol. 2011;9(7):577-83. doi: 10.1016/j. cgh.2011.03.026.

45. King SK, Sutcliffe JR, Ong SY, et al. Substance P and vasoactive intestinal peptide are reduced in right transverse colon in pediatric slow-transit constipation. Neurogastroenterol Motil. 2010 Aug;22(8):883-92. doi: 10.1016/j.cgh.2011.03.026.

46. Knowles CH, Grossi U, Chapman M, et al. Surgery for constipation: systematic review and practice recommendations: results I: colonic resection. Colorectal Dis. 2017;19(Suppl 3):17-36. doi: 10.1111/codi. 13779 . 
47. Knowles CH, Scott M, Lunniss PJ. Outcome of colectomy for slow transit constipation. Ann Surg. 1999;230:627-38. doi: 10.1097/00000658-199911000-00004.

48. Lacy BE, Mearin F, Chang L, et al. Bowel disorders. Gastroenterology. 2016;150(6):1393-407. doi: 10.1053/j.gastro.2016.02.031

49. Lane W.A. Chronic constipation and its medical and surgical treatment. British medical journal.1905;1.2309:700. doi: 10.1136/ bmj.1.2309.700.

50. Lembo AJ, Schneier HA, Shiff SJ, et al. Two randomized trials of linaclotide for chronic constipation. N Engl J Med. 2011;365(6):527-36. doi: 10.1056/NEJMoa1010863.

51. Li F, Fu T, Tong WD, et al. Lubiprostone is effective in the treatment of chronic idiopathic constipation and irritable bowel syndrome: a systematic review and metanalysis of randomized controlled trials. Mayo Clin Proc. 2016;91(4):456-68. doi: 10.1016/j. mayocp.2016.01.015.

52. Lim YJ, Rosita J, Chieng JY, Hazizi AS. The prevalence and symptoms characteristic of functional constipation using Rome III diagnostic criteria among tertiary education students. PLOS ONE 2016;11:e0167243.. doi: 10.1371/journal.pone.0167243

53. Ludvigsson JF. Epidemiological study of constipation and other gastrointestinal symptoms in 8000 children. Acta Paediatr. 2006;95:573-80. doi: 10.1080/08035250500452621.

54. Luthra P, Burr NE, Brenner DM, et al. Efficacy of pharmacological therapies for the treatment of opioid induced constipation: systematic review and network metanalysis. Gut. 2018 May 5. Epub ahead of print. doi: 10.1136/gutjnl-2018-316001.

55. Major, Giles, et al. Demonstration of differences in colonic volumes, transit, chyme consistency, and response to psyllium between healthy and constipated subjects using magnetic resonance imaging. Neurogastroenterology \& Motility 30.9 (2018):e13400. doi: 10.1111/nmo.13400.

56. Mearin F, Lacy BE, Chang L, et al. Bowel disorders. In: Drossman DA, Chang L, Chey WD, Kellow J, Tack J, Whitehead WE, eds. ROME IV, Functional Gastrointestinal Disorders.-Disorders of gut-brain interactions, 4th ed. Raleigh, NC: The Rome Foundation; 2016. P. 967-1058.

57. Mueller-Lissner S, Kamm MA, Wald A et al Multicenter, 4-week, double-blind, randomized, placebo-controlled trial of sodium picosulfate in patients with chronic constipation. Am J Gastroenterol. 2010;105(4):897-903. doi: 10.1038/ajg.2010.41.

58. Mugie SM, Benninga MA, Di Lorenzo C. Epidemiology of constipation in children and adults: a systematic review. Best Pract Res Clin Gastroenterol. 2011;25:3-18. doi: 10.1016/j.bpg.2010.12.010.

59. Nakajima A, Seki M, Taniguchi S, et al. Safety and efficacy of elobixibat for chronic constipation: results from a randomized, double-blind, placebo-controlled, phase 3 trial and an open label, single arm, phase 3 trial. Lancet Gastroenterol Hepatol. 2018;3(8):537-47. doi: 10.1016/S2468-1253(18)30123-7.

60. Ostwani W, Dolan J, Elitsur Y. Familial clustering of habitual constipation: a prospective study in children from West Virginia. J Pediatr Gastroenterol Nutr. 2010;50:287-9. doi: 10.1097/ MPG.0b013e3181a0a595.

61. Palsson OS, Whitehead WE, van Tilburg MAL, et al. Development and validation of the Rome IV diagnostic questionnaire for adults. Gastroenterology. 2016;150:1481-91. doi: 10.1053/j. gastro.2016.02.014

62. Peppas G, Alexiou VG, Mourtzoukou E, Falagas ME. Epidemiology of constipation in Europe and Oceania: a systematic review. BMC Gastroenterol. 2008;8:5. doi: 10.1186/1471-230X-8-5.

63. Pikarsky AJ, Singh JJ, Weiss EG, Nogueras JJ, Wexner SD. Long term follow-up of patients undergoing colectomy for colonic inertia. Dis Colon Rectum. 2001;44:179-83. doi: 10.1007/ BF02234290.

64. Pilkington SA, et al. Surgery for constipation: systematic review and practice recommendations: Results V: Sacral Nerve Stimulation. Colorectal Disease, 2017;19:92-100. doi: 10.1111/ codi. 13780.

65. Power AM, Talley NJ, Ford AC. Association between constipation and colorectal cancer: systematic review and metanalysis of observational studies. Am J Gastroenterol. 2013;108(6):894-903. quiz 904. doi: 10.1038/ajg.2013.52.

66. Prather CM. Subtypes of constipation: sorting out the confusion. Rev Gastroenterol Disord. 2004;4(Suppl 2):S11-6.

67. Probert CJ, Emmett PM, Heaton KW. Intestinal transit time in the population calculated from self-made observations of defecation J Epidemiol Community Health. 1993;47:331-3. doi: 10.1136/ jech.47.4.331.

68. Quigley EM, Tack J, Chey WD, et al. Randomized clinical trials: linaclotide phase 3 studies in IBS-C - a prespecified further analysis based on European medicines agency-specified endpoints. Aliment Pharmacol Ther. 2013;37(1):49-61. doi: 10.1111/apt.12123.
69. Rao S, Lembo AJ, Shiff SJ, et al. A 12-week, randomized, controlled trial with a 4-week randomized withdrawal period to evaluate the efficacy and safety of linaclotide in irritable bowel syndrome with constipation. Am J Gastroenterol. 2012;107(11):1714-24. quiz p.1725. doi: 10.1038/ajg.2012.255.

70. Rao SS, Bharucha AE, Chiarioni G, et al. Functional anorectal disorders. Gastroenterology. 2016;150(6):1430-42. doi: 10.1053/j. gastro.2016.02.009.

71. Rao SS, Ozturk R, Laine L. Clinical utility of diagnostic tests for constipation in adults: a systematic review. Am J Gastroenterol. 2005;100:1605-15. doi: 10.1111/j.1572-0241.2005.41845.x.

72. Rao SS, Patcharatrakul T. Diagnosis and treatment of dyssynergic defecation. J Neurogastroenterol Motil. 2016;22(3):423-35. doi: $10.5056 /$ jnm 16060

73. Rao SSC, Go JT, Valestin J, et al. Home biofeedback for the treatment of dyssynergic defecation: does it improve quality of life and is it cost-effective? Am J Gastroenterol. 2019;114(6):938-44. doi: 10.14309/ajg.0000000000000278.

74. Schmidt FM, Santos VL. Prevalence of constipation in the general adult population: an integrative review. J Wound Ostomy Continence Nurs. 2014;41:70-6. doi: 10.1097/01. WON.0000438019.21229.b7.

75. Schmulson MJ, Drossman DA. What is new in Rome IV. J Neurogastroenterol Motil. 2017;23:151-63. doi: 10.5056/jnm16214.

76. Serra Jordi, et al. European society of neurogastroenterology and motility guidelines on functional constipation in adults. Neurogastroenterology \& Motility. 2020;32.2:e13762. doi: 10.1111/ nmo.13762.

77. Sjolund K, Fasth S, Ekman R, et al. Neuropeptides in idiopathic chronic constipation (slow transit constipation). Neurogastroenterol Motil. 1997:9:143-50. doi: 10.1046/j.1365-2982.1997.d0146.x.

78. Sood R, Ford AC. Rome IV criteria for FGIDs - an improvement or more of the same?: Diagnosis. Nat Rev Gastroenterol Hepatol. 2016;13:501-2. doi: 10.1038/nrgastro.2016.110.

79. Spijkerman M, Tan IL, Kolkman JJ, et al. A large variety of clinical features and concomitant disorders in celiac disease - A cohort study in the Netherlands. Dig Liver Dis. 2016;48(5):499-505. doi: 10.1016/j.dld.2016.01.006.

80. Suares NC, Ford AC. Prevalence of, and risk factors for, chronic idiopathic constipation in the community: systematic review and metanalysis. Am J Gastroenterol. 2011;106(9):1582-1591. quiz 1581, 1592. doi: 10.1038/ajg.2011.164

81. Tack J, Müller-Lissner S, Stanghellini V, et al. Diagnosis and treatment of chronic constipation a European perspective: Diagnosis and treatment of chronic constipation. Neurogastroenterol Motil. 2011;23:697-710.. doi: 10.1111/j.1365-2982.2011.01709.x.

82. Talley NJ, Jones M, Nuyts G, Dubois D. Risk factors for chronic constipation based on a general practice sample. Am J Gastroenterol. 2003;98:1107-1111. doi: 10.1111/j.15720241.2003.07465.x.

83. Thompson WG, Longstreth GF, Drossman DA, Heaton KW, Irvine EJ, Muller-Lissner SA. Functional bowel disorders and functional abdominal pain. Gut. 1999; 45(Supplement 2):ii43-ii47. doi: 10.1136/gut.45.2008.ii43.

84. Tomita R, Fujisaki S, Ikeda T, Fukuzawa M. Role of nitric oxide in the colon of patients with slow transit constipation. Dis Colon Rectum. 2002;45:593-600. doi: 10.1007/s10350-004-6251-8.

85. Tomita R, Tanjoh K, Fujisaki S, Ikeda T, Fukuzawa M. Regulation of the enteric nervous system in the colon of patients with slow transit constipation. Hepatogastroenterology. 2002;49:1540-4. doi: 10.3748/wjg.v9.i9.2065.

86. Törnblom H, Van Oudenhove L, Sadik R, et al. Colonic transit time and IBS symptoms: what's the link? Am J Gastroenterol. 2012;107(5):754-60. doi: 10.1038/ajg.2012.5.

87. Webster C, Dayton M. Results after colectomy for colonic inertia: a sixteen-year experience. Am J Surg. 2001;182:639-44. doi 10.1016/s0002-9610(01)00820-0

88. Wedel T, Roblick UJ, Ott V, Eggers R, Schiedeck THK, Krammer HJ, Bruch HP. Oligoneural hypoganglionosis in patients with idiopathic slow-transit constipation. Dis Colon Rectum. 2002;45:54-62. doi: 10.1007/s10350-004-6114-3.

89. Wedel T, Spiegler J, Soellner S, et al. Enteric nerves and interstitial cells of Cajal are altered in patients with slow-transit constipation and megacolon. Gastroenterology. 2002;123:1459-67. doi 10.1016/s0002-9610(01)00820-0.

90. Xin HW, Fang XC, Zhu LM, et al. Diagnosis of functional constipation: Agreement between Rome III and Rome II criteria and evaluation for the practicality: FC diagnosis by Rome III and II criteria. J Digest Dis. 2014; 15:314-20. 


\title{
Хронічні запори: сучасний погляд на проблему. Огляд літератури
}

\author{
І. М. Лещишин, Я. М. Сусак, О. І. Охоцька, П. Л. Бик, Л. Ю. Маркулан, О. В. Панчук
}

Національний медичний університет імені О. О. Богомольця, Київ

Хронічний запор є поширеною гетерогенною патологією, що трапляється та значно погіршує якість життя в усіх групах населення. Їі частота збільшується з віком. Це зумовлено малорухливим способом життя, недостатньою кількістю харчових волокон і рідини в раціоні, широким спектром захворювань, які безпосередньо призводять до розвитку хронічного запору, інтеркурентних захворювань, зловживанням проносними або комбінацією зазначених чинників. Хронічні запори уражають приблизно $10-15 \%$ дорослого населення, значно погіршуючи якість життя. Оскільки є велика кількість розладів, що призводять до запорів, існують численні класифікації останніх, заснованих, зазвичай, на їхній етіології або механізмах. Для точної класифікації запорів використовуються різні критерії, але все ще важко знайти одну класифікацію, яка б охоплювала всі типи. Римські критерії IV класифікували розлади хронічного запору на чотири підгрупи. Лікування залежить від підтипу. Незважаючи на наявність публікацій, присвячених повільнотранзитним запорам, останні є предметом вивчення для багатьох фахівців у різних наукових галузях. Останніми роками багато наукових праць було присвячено імуногістохімічним дослідженням інтерстиціальних пейсмейкерних клітин. Виявлено маркери, які вони експресують. Головною метою сучасних вчених є розробка та впровадження нових лабораторних методів, які б остаточно визначили показання до хірургічного втручання з урахуванням виявлених порушень нейрофізіології кишечника і дали змогу диференційовано відбирати хворих для оперативного лікування. Поетапний підхід до діагностики хронічного запора дає змогу вибрати адекватний метод лікування з метою поліпшення симптомів та якості життя і підвищення задоволеності пацієнтів. Підсумовуючи огляд літератури 3 цієї проблеми, можна дійти висновку, що хірургічне втручання залишається найбільш радикальним методом лікування пацієнтів із повільнотранзитними запорами.

ключові слова: повільнотранзитний запор, проносні, тотальна колектомія, ілеоректоанастомоз.

I Leshchyshyn IM, Susak YM, Okhots'ka OI, Byk PL, Markulan LY, Panchuk OV. Chronic constipation: modern view on the problem. General Surgery (Ukraine). 2021:1;67-79. http://doi.org/10.30978/GS-2021-1-67.
} 